\title{
PERBEDAAN MENDASAR ANTROPOLOGI HUKUM, SOSIOLOGI HUKUM DAN HUKUM ADAT
}

\author{
Indra Jaya Saputra Waruwu \\ Email: indrajayasaputra1610@gmail.com \\ No BP: 2110003600251 \\ Universitas Eka Sakti Padang
}

\section{A. PENDAHULUAN}

Antropologi adalah ilmu tentang manusia. Antropologi berasal dari kata Yunani

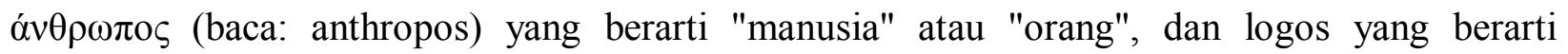
"wacana" (dalam pengertian "bernalar", "berakal") atau secara etimologis antropologi berarti ilmu yang mempelajari manusia. Dalam melakukan kajian terhadap manusia, antropologi mengedepankan dua konsep penting yaitu: Holistik dan Komparatif. Karena itu kajian antropologi sangat memperhatikan aspek sejarah dan penjelasan menyeluruh untuk menggambarkan manusia melalui pengetahuan ilmu sosial ilmu hayati (alam), dan juga humaniora.

Namun pada dasarnya sasaran pokok dalam antropologi adalah manusia, baru kemudian perilaku budayanya, tidaklah sebaliknya sebagaimana dalam ilmu yang lain. Dikarenakan perbedaan tempat dan lingkungan, perbedaan sejarah dan asal-usulnya, perbedaan semangat dan jiwanya, perbedaan akal dan cara berpikirnya, perbedaan budaya dan agama yang mempengaruhinya, maka perilaku budaya manusia itu berbeda-beda antara yang satu dan yang lain. Jadi tidak ada suatu sistem pola perilaku manusia yang seragam, dan oleh karenanya tidak ada pula sistem pola kepribadian manusia itu yang sama. 
Antropologi bertujuan untuk lebih memahami dan mengapresiasi manusia sebagai entitas biologis homo sapiens dan makhluk sosial dalam kerangka kerja yang interdisipliner dan komprehensif. Oleh karena itu, antropologi menggunakan teori evolusi biologi dalam memberikan arti dan fakta sejarah dalam menjelaskan perjalanan umat manusia di bumi sejak awal kemunculannya. Antropologi juga menggunakan kajian lintas-budaya (Inggris crosscultural) dalam menekankan dan menjelaskan perbedaan antara kelompok-kelompok manusia dalam perspektif material budaya, perilaku sosial, bahasa, dan pandangan hidup.

Dengan orientasinya yang holistik, antropologi dibagi menjadi empat cabang ilmu yang saling berkaitan, yaitu: Antropologi Biologi, Antropologi Sosial Budaya, Arkeologi, dan Linguistik. Keempat cabang tersebut memiliki kajian-kajian konsentrasi tersendiri dalam kekhususan akademik dan penelitian ilmiah, dengan topik yang unik dan metode penelitian yang berbeda-beda.

Antropologi lahir atau berawal dari ketertarikan orang-orang Eropa pada ciri-ciri fisik, adat istiadat, dan budaya etnis-etnis lain yang berbeda dari masyarakat yang dikenal di Eropa. Pada saat itu kajian antropologi lebih memusatkan pada penduduk yang merupakan masyarakat tunggal, tunggal dalam arti kesatuan masyarakat yang tinggal di suatu kawasan geografis yang sama, memiliki ciri fisik dan bahasa yang digunakan serupa, serta cara hidup yang sama. Namun demikian dalam perkembangannya, ilmu antropologi kemudian tidak lagi hanya mempelajari kelompok manusia tunggal yang mendiami suatu wilayah geografis yang sama. Kajian-kajian antropologi mengenai isu-isu migrasi misalnya kemudian melahirkan penelitian-penelitian etnografis multi-situs. Hal ini terjadi karena dalam perkembangannya, pergerakan manusia baik dalam satu kawasan regional tertentu hingga dalam cakupan global adalah fenomena yang semakin umum terjadi. 
Sosiologi hukum sendiri mempunyai objek kajian fenomena hukum, sebagaimana telah dituliskan oleh Curzon, bahwa Roscou Pound menunjukkan studi sosiologi hukum sebagai studi yang didasarkan pada konsep hukum sebagai alat pengendalian sosial. Sementara Llyod, memandang sosiologi hukum sebagai suatu ilmu deskriptif, yang memanfaatkan teknis-teknis empiris. Hal ini berkaitan dengan perangkat hukum dengan tugas-tugasnya.Ia memandang hukum sebagai suatu produk sistem sosial dan alat untuk mengendalikan serat mengubah sistem itu.

\section{B. PEMBAHASAN}

\section{Antropologi Hukum}

Antropologi hukum adalah salah satu ilmu yang saat ini masih dalam tahap pertumbuhan. Ini mempelajari kekhasan bentuk hukum aktivitas manusia dalam periode sejarah yang berbeda dan dalam keadaan yang sama sekali berbeda. Bagi para peneliti, pengembangan bidang ini sangat penting karena membantu untuk mengenal keragaman hukum dunia dan untuk melihat hukum melalui sudut pandang persepsi perwakilan dari berbagai bangsa dan budaya.

Antropologi hukum pada dasarnya adalah sub disiplin ilmu hukum empiris yang memusatkan perhatiannya pada studi-studi hukum dengan menggunakan pendekatan antropologis. Kendati demikian, dari sudut pandang antropologi, sub disiplin antropologi budaya yang memfokuskan kajiannya pada fenomena empiris kehidupan hukum dalam masyarakat secaraluas dikenal sebagai antropologi hukum. Antropologi hukum pada dasarnya mempelajari hubungan timbal-balik antara hukum dengan fenomena-fenomenasosial secara empiris dalam kehidupan masyarakat; bagaimana hukum berfungsidalam kehidupan masyarakat, atau bagaimana hukum bekerja sebagai alat pengendalian sosial (social control) atau sarana untuk 
menjaga keteraturan sosial (social order) dalam masyarakat. Dengan kata lain, studi-studi antropologis mengenai hukum memberi perhatian pada segi-segi kebudayaan manusia yang berkaitan dengan fenomena hukum dalam fungsinya sebagai sarana menjaga keteraturan sosial atau alat pengendalian social.

\section{Sosiologi Hukum}

Sosiologi hukum pada hakekatnya dua istilah ilmu yang menjadi satu, yakni kata Sosiologi yang memiliki arti ilmu pengetahuan tentang masyarakat dan Hukum yang bermakna aturan yang terjadi karenanya penyesuaian terhadap berbagai bentuk gejala sosial yang ada dalam masyarakat. Oleh karena itulah sosiologi hukum dianggap sebagai ilmu pengetahuan yang mengkaji kehidupan masyarakat dalam pandangan ilmu hukum, sebagai upaya menciptakan keteraturan sosial yang terjadi di dalamnya.

Sosiologi hukum adalah ilmu pengetahuan yang empiris analitis sebagai bentuk mendalami tentang hubungan-hubungan yang karena gejala sosial yang terjadi dalam masyarakat. Baik dilihat dari arti lembaga hukumnya, pranata sosial, dan bentuk perubahan sosial. Adapun definisi sosiologi hukum menurut para ahli, antara lain;

1. Brade Meyer, Definisi sosiologi hukum dalam pandangannya adalah ilmu pengetahuan yang memusatkan hukum sebagai penelitian sosial, sehingga dalam upaya tersebut akan melihat pandangan masyarakat terhadap peraturan yang terjadi serta dampak yang ditimbulkannya. Ia menambahkan bahwa dalam penelitian yang dilakukan lebih fokus dalam gejala sosial sebagai tindakan melihat kepastian hukum.

2. Mochtar Kusumaatmadja, Pengertian sosiologi hukum adalah ilmu pengetahuan yang menitikberatkan pada kaidah dan asas di dalam kehidupan manusia. Hingga akhirnya disiplin ilmu ini akan membawa ketentraman dan keteraturan bersama antar masyarakat. 
3. Soerjono Soekanto, Arti sosiologi hukum adalah cabang ilmu pengetahuan yang dikaji dalam sususnan analitis dan empiris di dalam menganalisis hubungan timbal balik gejala sosial dan berbagai bentuk perosalan hukum yang ada dalam masyarakat.

4. Satjipto rahardjo, Pengertian sosiologi hukum ialah pengetahuan materi tentang hukum yang dikaji dalam persolan prilaku sosial yang ada di dalam kehidupan bermasyarakat

5. R.Otje Salman, Sosiologi hukum adalah hubungan sosial dan hukum yang diperjelas dengan adanya timbal balik antara hukum dengan gejala sosial melalui suatu kajian yang analisis dan empiris.

6. Soetandyo Wignjosoebroto, Sosiologi hukum adalah dalam pandangannya adalah cabang kajian sosiologi yang menitikbertakan pada peroslan hukum sebagaiman sebagai upaya menciptakan keteraman dan kebersahaan dalam bermasyarakat.

7. David N. Schiff, Sosiologi hukum adalah disiplin ilmu sosiologi yang mengkaji tentang berbagai bentuk fenomena hukum baik secara tindakan, pola prilaku, dan dampak yang ditimbulkan dalam masyarakat.

\section{Hukum Adat}

Hukum adat merupakan hukum asli Indonesia yang tidak terkodifikasi dalam peraturan perundang-undangan nasional. Hukum yang sejak dahulu telah ditaati oleh masyarakat adat di berbagai daerah di Indonesia, dan di akui hingga sekarang sebagai salah satu hukum yang sah, hukum yang sepenuhnya berlaku di Tanah Air. Banyak contoh yang mengakui kedudukan hukum adat dam hukum islam di Indonesia dapat dilihat dari pembentukan undang-undang yang isinya mencorakkan hukum adat dan hukum Islam dari undang-undang perkawinan, UUPA, dan juga Salah satu ciri yang signifikan dalam unsur hukum adat dengan adanya peleburan ajaran agama yang tak mungkin dikesampingkan karena masyarakat Indonesia tak lepas dari unsur 
agama yang menjadi dasar dalam pemberlakuan hukum adat. Saat ini, hukum adat masih diterapkan oleh berbagai masyarakat adat Indonesia, hukum yang mengatur perihal warisan adat, perkawinan adat, dan hal-hal lain yang mengatur regulasi dalam suatu budaya kultural. Jenis hukum tertua yang pernah dimiliki oleh Indonesia sampai saat ini masih diterapkan oleh masyarakat, dan diakui oleh negara. Berikut pengertian hukum adat menurut para ahli, yaitu :

1. Pengertian hukum adat menurut Prof. Dr. Cornellis Van Vollenhoven sebagai seorang yang pertama-tama menjadikan hukum adat sebagai ilmu pengetahuan, sehingga hukum adat menjadi sejajar kedudukannya dengan hukum lain di dalam ilmu hukum menyatakan sebagai berikut: "Hukum adat adalah aturan-aturan perilaku yang berlaku bagi orang pribumi dan orang-orang timur asing yang disatu pihak mempunyai sanksi (maka dikatakan sebagai hukum) dan dilain pihak tidak dikodifikasikan (maka dikatakan adat)”.

2. Pengertian hukum adat menurut Soejono Soekanto, beliau menyatakan bahwa hukum adat adalah hukum adat pada hakikatnya merupakan hukum kebiasaan, artinya Kebiasaan-kebiasaan yang mempunyai akibat hukum. Kebiasaan yang merupakan hukum adat adalah perbuatan yang diulang-ulang dalam bentuk yang sama.

3. Prof. Dr. Soepomo, S.H. Hukum adat adalah hukum tidak tertulis didalam peraturan tidak tertulis, meliputi peraturan-peraturan hidup yang meskipun tidak ditetapkan oleh yang berwajib tetapi ditaati dan didukung oleh rakyat berdasarkan atas keyakinan bahwasanya peraturan-peraturan tersebut mempunyai kekuatan hukum

Hukum adat merupakan hukum tradisional masyarakat yang merupakan perwujudan dari suatu kebutuhan hidup yang nyata serta merupakan salah satu cara pandangan hidup yang secara keseluruhannya merupakan kebudayaan masyarakat tempat hukum adat tersebut berlaku. Hukum adat juga merupakan nilai-nilai yang hidup dan berkembang di dalam masyarakat suatu daerah. 
Walaupun sebagian besar hukum adat tidak tertulis, namun ia mempunyai daya ikat yang kuat dalam masyarakat.

Ada sanksi tersendiri dari masyarakat jika melanggar aturan hukum adat. Hukum adat yang hidup dalam masyarakat ini bagi masyarakat yang masih kental budaya aslinya akan sangat terasa. Penerapan hukum adat dalam kehidupan sehari-hari juga sering diterapkan oleh masyarakat. Bahkan seorang hakim, jika ia menghadapi sebuah perkara dan ia tidak dapat menemukannya dalam hukum tertulis, ia harus dapat menemukan hukumnya dalam aturan yang hidup dalam masyarakat, artinya hakim juga harus mengerti perihal hukum adat. Hukum adat dapat dikatakan sebagai hukum perdatanya masyarakat Indonesia. Dari pengertian Hukum Adat yang diungkapkan di atas, bentuk Hukum Adat sebagian besar adalah tidak tertulis. Padahal, dalam sebuah negara hukum, berlaku sebuah asas yaitu asas legalitas. Asas legalitas menyatakan bahwa tidak ada hukum selain yang dituliskan di dalam hukum. Hal ini untuk menjamin kepastian hukum. Namun di suatu sisi bila hakim tidak dapat menemukan hukumnya dalam hukum tertulis, seorang hakim harus dapat menemukan hukumnya dalam aturan yang hidup dalam masyarakat. Diakui atau tidak, namun Hukum Adat juga mempunyai peran dalam Sistem Hukum Nasional di Indonesia. Hukum adat yang dimaksud disini adalah hukum yang tidak tertulis tercantum pada pasal 25 (1) dan pasal 28 (1) dalam Undang-Undang tentang ketentuan ketentuan pokok kekuasaan kehakiman nomor 4 tahun 2004 yang menjelaskan pada intinya memungkinkan bahwasanya hukum adat yang tidak tertulis bisa menjadi dasar Hakim dalam menjatuhkan suatu putusan. 


\section{Perbedaan Antropologi Hukum, Sosiologi Hukum dan Hukum Adat}

- Perbedaan Antropologi Hukum dan Sosiologi Hukum

\begin{tabular}{|c|c|c|c|}
\hline N0 & Jenis & Antropologi Hukum & Sosiologi Hukum \\
\hline 1 & Proses & $\begin{array}{l}\text { Awalnya temukan dulu faktanya (Social facts), } \\
\text { kemudian dipilahpilah mana yang merupakan } \\
\text { budaya hukum, lalu dibuat konstruksi hukumnya } \\
\text { dan terakhir dianalisis untuk ditemukan maknanya } \\
\text { yang mempunyai ciri-ciri khusus, sebagai } \\
\text { penjabaran dari jalinan nilai budaya }\end{array}$ & $\begin{array}{l}\text { Awalnya temukan } \\
\text { faktanya (social } \\
\text { facts) kemudian } \\
\text { dipilahpilah mana } \\
\text { yang merupakan } \\
\text { kenyataan hukum } \\
\text { lalu dibuat } \\
\text { konstruksi } \\
\text { hukumnya, } \\
\text { selanjutnya } \\
\text { dianalisis dengan } \\
\text { perundang- } \\
\text { undangan/kaedah } \\
\text { hukumnya, terakhir } \\
\text { disimpulkan }\end{array}$ \\
\hline 2. & Kajian & $\begin{array}{l}\text { Mengkaji hukum dengan mempelajari hukum } \\
\text { dengan latar belakang budayanya seperti } \\
\text { sejarah,lingkungan hidup, keluarga, pemukiman, } \\
\text { politik dsb. }\end{array}$ & $\begin{array}{l}\text { Mengkaji hubungan } \\
\text { timbal balik antara } \\
\text { hukum dan gejala } \\
\text { sosial yg ada di } \\
\text { dalam masyarakat } \\
\text { yang dilakukan } \\
\text { secara analitis dan } \\
\text { empiris (sesuai } \\
\text { dengan } \\
\text { kenyatannya). }\end{array}$ \\
\hline 3 & Kekurangan & $\begin{array}{l}\text { Terletak pada ketidak seragamannya hukum dan } \\
\text { proses penyelesaian masalah karena berdasarkan } \\
\text { latar belakang kebudayaan dari hukum itu sendiri. }\end{array}$ & $\begin{array}{l}\text { Hanya sebatas } \\
\text { mengkaji hubungan } \\
\text { timbal balik antar } \\
\text { hukum dengan } \\
\text { gejala sosial akan } \\
\text { tetapi tidak } \\
\text { mengkaji faktor } \\
\text { yang menyebabkan } \\
\text { penyimpangan dari } \\
\text { hukum itu sendiri }\end{array}$ \\
\hline 4. & Kelebihan & $\begin{array}{l}\text { Melalui kajian antropolgi maka hukum dapat di } \\
\text { ketahui latar belakang kebudayaanya. }\end{array}$ & $\begin{array}{l}\text { Objek yang di kaji } \\
\text { benar benar sesuai } \\
\text { kenyataan, dan } \\
\text { tidak bersifat } \\
\text { spekulatif. }\end{array}$ \\
\hline 5. & Persepektif & Budaya Sosial & Budaya Sosial \\
\hline
\end{tabular}




\begin{tabular}{|c|c|l|l|}
\hline 6. & Penelitian & Kualitatif, Studi Kasus & Kuantitaif, Sampel \\
\hline 7. & Objek & Hukum bukan Barat, Tidak tertulis & $\begin{array}{l}\text { Hukum barat / yang } \\
\text { telah dipengaruhi } \\
\text { hukum tertulis }\end{array}$ \\
\hline 8. & Subjek & Masyarakat Sederhana & Masyarakat Modern \\
\hline
\end{tabular}

- Perbedaan Antropologi Hukum dan Hukum Adat

\begin{tabular}{|c|c|l|l|}
\hline NO & Jenis & \multicolumn{1}{|c|}{ Antropologi Hukum } & \multicolumn{1}{|c|}{ Hukum Adat } \\
\hline 1. & Pendekatan & Holistik & Yuridis Normatif \\
\hline 2. & Objek & Perilaku Manusia & $\begin{array}{l}\text { Norma Hukum di } \\
\text { luar UU }\end{array}$ \\
\hline 3. & Norma & Norma kenyataan & Dikehendaki \\
\hline 4. & Sifat & Penelitian Penelitian Lapangan & $\begin{array}{l}\text { Studi pustaka dan } \\
\text { dokumen }\end{array}$ \\
\hline
\end{tabular}

\section{PENUTUP}

Antropologi hukum ialah ilmu pengetahuan yang berkaitan dengan manusia yang bersangkutan dengan hukum. Dimana Antropologi hukum pada dasarnya mempelajari hubungan timbal-balik antara hukum dengan fenomena-fenomena sosial secara empiris dalam kehidupan masyarakat; bagaimana hukum berfungsi dalam kehidupan masyarakat, atau bagaimana hukum bekerja sebagai alat pengendalian sosial (social control) atau sarana untuk menjaga keteraturan sosial (social order) dalam masyarakat.

Sosiologi hukum merupakan studi hukum dalam perspektif ilmu sosial yang merupakan sebuah ikhtiar melakukan konstruksi hukum yang didasarkan pada fenomena sosial yang ada. Perilaku masyarakat yang dikaji adalah perilaku yang timbul akibat berinteraksi dengan sistem norma yang ada. Interaksi itu muncul sebagai bentuk reaksi masyarakat atas diterapkannya sebuah ketentuan perundang-undangan positif dan bisa pula dilihat prilaku masyarakat sebagai bentuk aksi dalam memengaruhi pembentukan sebuah ketentuan hukum positif. kajian sosiologi hukum adalah suatu kajian yang objeknya fenomena hukum, tetapi menggunakan optik ilmu 
sosial dan teori-teori sosiologis, sehingga sering disalahtafsirkan bukan hanya oleh kalangan non hukum, tetapi juga dari kalangan hukum sendiri.

Hukum adat merupakan hukum asli Indonesia yang tidak terkodifikasi dalam peraturan perundang-undangan nasional. Hukum adat merupakan hukum tradisional masyarakat yang merupakan perwujudan dari suatu kebutuhan hidup yang nyata serta merupakan salah satu cara pandangan hidup yang secara keseluruhannya merupakan kebudayaan masyarakat tempat hukum adat tersebut berlaku. Hukum adat juga merupakan nilai-nilai yang hidup dan berkembang di dalam masyarakat suatu daerah. Ada sanksi tersendiri dari masyarakat jika melanggar aturan hukum adat. 


\section{DAFTAR PUSTAKA}

Darmini Roza dan Laurensius Arliman S, Peran Pemerintah Daerah Di Dalam Melindungi Hak Anak Di Indonesia, Masalah-Masalah Hukum, Volume 47, Nomor 1, 2018. https://doi.org/10.14710/mmh.47.1.2018.10-21

Laurensius Arliman S, Peranan Metodologi Penelitian Hukum di Dalam Perkembangan Ilmu Hukum di Indonesia, Soumatera Law Review, Volume 1, Nomor 1, 201. http://doi.org/10.22216/soumlaw.vli1.3346.

Laurensius Arliman S, Peran Badan Permusyawaratan Desa di Dalam Pembangunan Desa dan Pengawasan Keuangan Desa, Padjadjaran Journal of Law, Volume 4, Nomor 3, 2017. https://doi.org/10.15408/jch.v4i2.3433.

Laurensius Arliman S, Penanaman Modal Asing Di Sumatera Barat Berdasarkan UndangUndang Nomor 25 Tahun 2007 Tentang Penanaman Modal, Supremasi Hukum, Volume 1, Nomor 1, 2018. http://dx.doi.org/10.36441/hukum.v1i01.102 .

Laurensius Arliman S, Memperkuat Kearifan Lokal Untuk Menangkal Intoleransi Umat Beragama Di Indonesia, Ensiklopedia of Journal, Volume 1, Nomor 1, 2018, https://doi.org/10.33559/eoj.vli1.18.

Laurensius Arliman S, Perkawinan Antar Negara Di Indonesia Berdasarkan Hukum Perdata Internasional, Kertha Patrika, Volume 39, Nomor 3, 2017, https://doi.org/10.24843/KP.2017.v39.i03.p03.

Laurensius Arliman S, Partisipasi Masyarakat Di Dalam Pengelolaan Uang Desa PascaUndangUndang Nomor 6 Tahun 2014 Tentang Desa, Jurnal Arena Hukum, Volume 12, Nomor 2, 2019, https://doi.org/10.21776/ub.arenahukum.2019.01202.5.

Laurensius Arliman S, Mewujudkan Penegakan Hukum Yang Baik Di Negara Hukum Indonesia, Dialogica Jurnalica, Volume 11, Nomor 1, 2019, https://doi.org/10.28932/di.v11il.1831.

Laurensius Arliman S, Mediasi Melalui Pendekatan Mufakat Sebagai Lembaga Alternatif Penyelesaian Sengketa Untuk Mendukung Pembangunan Ekonomi Nasional, UIR Law Review, Volume 2, Nomor 2, 2018, https://doi.org/10.25299/uirlrev.2018.vol2(02).1587

Laurensius Arliman S, Peranan Filsafat Hukum Dalam Perlindungan Hak Anak Yang Berkelanjutan Sebagai Bagian Dari Hak Asasi Manusia, Doctrinal, Volume 1, Nomor 2,2016.

Laurensius Arliman S, Ni Putu Eka Dewi, Protection of Children and Women's Rights in Indonesiathrough International Regulation Ratification, Journal of Innovation, Creativity and Change Volume 15, Nomor 6, 2021.

Laurensius Arliman S, Gagalnya Perlindungan Anak Sebagai Salah Satu Bagian Dari Hak Asasi Manusia Oleh Orang Tua Ditinjau Dari Mazhab Utilitarianisme, Jurnal Yuridis, Volume 3, Nomor 2, 2016, http://dx.doi.org/10.35586/.v3i2.180.

Laurensius Arliman S, Tantangan Pendidikan Kewarganegaraan Pada Revolusi 4.0, Jurnal Ensiklopedia Sosial Review, Volume 2, Nomor 3, $2020 .$. 
